\title{
Nicolas Bréhal: Writing as Self-Preservation
}

\author{
David J. Bond \\ University of Saskatchewan
}

Do not imagine that art is something which is designed to give gentle uplift and self-confidence. Art is not a brassière. At least, not in the English sense.

But do not forget that brassière is the French for life-jacket.

Julian Barnes, Flaubert's Parrot.

Ticolas Bréhal's novels have been praised for their delicate, muted 1 style, and he is often compared to the Romantics. His style is described as "lisse et limpide," and as containing "quelque chose de doux, de contemplatif, de particulièrement soigné." ${ }^{1}$ One critic calls him "notre romantique le plus mesuré, le plus délicieux, le plus grave et le plus précis." ${ }^{2}$ However, little attempt has been made to go beyond these flattering comparisons and comments on style. Justified though this praise undoubtedly is, one feels that there is more to Bréhal's work than this. It is as though critics are unsure of what exactly lies behind the beautiful prose, or whether there is some common thread linking his novels together, other than a resemblance to certain Romantics. The comment made by one critic concerning the novel Les Étangs de Woodfield might sum up the attitude of critics to all of Bréhal's work: "Ce livre est étrange et beau, un peu comme une musique dont nous n'avons pas la clef harmonique, mais qui nous imprègne jusqu'à l'ensorcellement."

I would like to suggest that the "key" to Bréhal's work lies in the way it depicts and attempts to create a secure environment in a world of hostile forces. This is evident most clearly at the diegetic level, for his novels all 


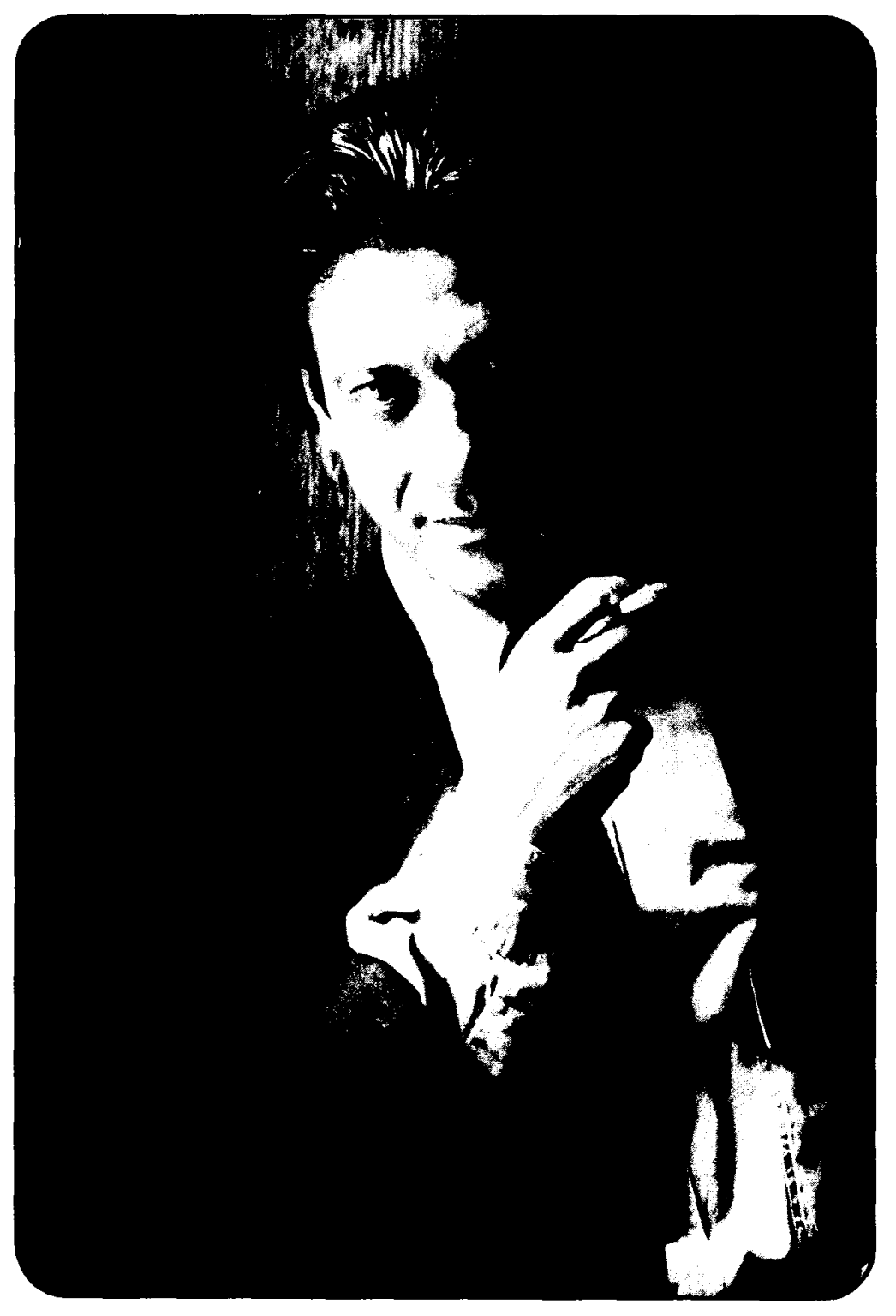

Nicolas BréHAL 
show groups of people who live in sheltered communities in which they seek to protect themselves. ${ }^{4}$ Les Étangs de Woodfield is the story of Jane and Deborah Lockwood, two sisters brought up by their aunt in a large house set in extensive grounds. This secluded home is itself part of the privileged world of the rich bourgeois, who live in a district deliberately isolated from the working-class area on the other side of the river. Portrait de femme, l'automne recounts a few days in the life of Charlotte, a novelist who has invited a group of friends and relatives to celebrate her fiftieth birthday in the isolated house that she shares with her husband. Surrounded by a large park, the house was bought because she needed "un endroit où [elle] se sentît en complète sécurité" (26). Within her home, her study forms a "chambre interrieure" (94) to which she withdraws at times of crisis. La Pâleur et le sang is set on an island in the Atlantic called Vindilis, on which lives a fishing and farming community. Frequently cut off from the mainland, the islanders are a tightly-knit group that shuns the outside world. "Nous remerciions le hasard de nous avoir fait naître détachés du reste du pays," says the narrator (15). The Bowley family reigns over the island, almost like feudal lords. Their house, set apart from the main centres of population, is a world within a world. In L'Enfant au souffle coupé, the young Daniel lives with his mother and two aunts in a protected environment in which, he says, "je me sentais protégé des tempêtes, des orages" (23). Laurent Kreutzer, the dying concert pianist in Sonate au clair de lune is surrounded by his family as the New Year and a new century approach. Lying in his silent, darkened room in a house that has been his protection from the rest of the world for many years, he feels that: "Quoi qui puisse périr et disparaître ailleurs, ce qui se trouve ici est bien solide" (49).

Living in these self-contained groups, Bréhal's characters create for themselves a sense of communion and unity. Laurent Kreutzer's daughter urges the assembled members of her family: "Soyons unis! Restons unis!" (Sonate au clair de lune, 203), and his wife, as she contemplates them all gathered for the New Year, says to herself: "Nous sommes entre nous. C'est parfait. Nous sommes unis" (203). This communion is an attempt to establish an order, a realm that follows fixed rules and that stands 
firm in a changing world. Charlotte in Portrait de femme, l'automne is offended by disorder within her house, and she insists that everything be kept tidy. The Bowley house is run according to fixed rules, and we are told that: "Un ordre austère régna dans la maison des Bowley" ( $L a$ Pâleur et le sang, 40). The streets of Woodfield and of the nearby town of John-Libourg are set out in a grid pattern that forms "[un] alignement sans faille" (Les Étangs de Woodfield, 72). The park surrounding the Lockwood house is likewise organised in a tidy pattern in which " 1 'ordre était si rigoureux, si maintenu" (70).

Yet the individuals who live in these ordered groups feel that they are threatened and that their world is fragile. The whole social order in Woodfield is precarious, and one of the privileged warns: "A Woodfield, c'est paradoxal, on est fragile d'exister" (Les Étangs de Woodfield, 38). Within the Lockwood house, as Jane puts it: "Des années ont passé, le même ordre règne, mais fragile" (87). Kreutzer's daughter, meditating on the shelter afforded by the home in which she grew up, declares: "Que cette maison d'apparence si claire, si lumineuse, était une construction fragile" (Sonate au clair de lune, 141).

Foremost among the powers that threaten their world is time. Although the isolated communities are an attempt to create lasting order, the passage of time undermines that order. One of the characters in Les Étangs de Woodfield sees that time will change the relationships that constitute stability in her world, and she writes: "Le temps se dresse devant moi de toute sa hauteur, mauvaise herbe géante enracinée à Woodfield" (49). Portrait de femme, l'automne begins as Charlotte celebrates her fiftieth birthday, filled with malaise at the thought of her life seeping ever more rapidly away. The order that she has established in her home seems suddenly precarious, and she wonders: "Pourquoi fallait-il que le Temps vienne tout déranger?" (67). But it is in Sonate au clair de lune that the burden of time is the most oppressive. Set when one century ends and another begins, it is saturated by the anguish provoked by time. Laurent Kreutzer hopes desperately to hold off his death until the new century has come, feeling that this will constitute some small victory over time. Consequently, his every moment is suffused by 
awareness of time, and every memory that enters his mind becomes "la preuve que le temps passe" (17). The other members of the family are infected by his anguish, and see that the apparently immutable order of their lives is an illusion. "Et le temps nous trompe," concludes his daughter (92). As she and her husband drift apart, she realises that emotions and relationships are also subject to the passage of time: "Les êtres et les choses ont leur temps...Même l'amour finit en poussière" (130).

Linked to time is the threat of death. The fear of death is an integral part of the lives of Bréhal's characters, despite their attempts to deny its presence. When Daniel looks at the garden surrounding his house, he sees the plants dying at the approach of winter, and he is reminded of his own mortality. Jane Lockwood's mother died at her birth, and this is constantly at the edge of her awareness. Les Etangs de Woodfield is, in fact, informed throughout by death, for Jane's aunt dies, as does her father and the man whom Deborah loves. Deborah herself disappears, and is presumed dead. Charlotte in Portrait de fermme, l'automne is reminded by her birthday that her mother died at this age, and memories of a beloved brother's death flood back. Laurent Kreutzer's fear that he may die before the new century begins influences the rest of the family, and we are told that an "odeur de mort flottait dans chaque pièce de la maison" (Sonate au clair de lune, 58). Louise Labé's lines, quoted three times in the novel, sum up the characters' fears: "Je vis, je meurs, je me brule et me noye/ J'ay chaut estreme en endurant froidure" $(16,109,136)$.

La Pâleur et le sang paints a similar picture of a world threatened, but on a more mystical and fantastic level. Here, the forces that assail the island are seen as having a mysterious, almost diabolical origin. They manifest themselves in the waves that pound Vindilis, the unusually fierce winds, the freezing cold and snow. Nature is stirred up against the islanders because the supernatural powers that control it are offended by certain characters. So incensed are they by the behaviour of some islanders that they cause the fish to desert the island's waters, the crops to fail, and fishing boats to be wrecked on the rocks. As one islander says: "Visiblement, les forces de l'île veulent notre perdition" (64). 
The old woman known as la Groac' $h$ in La Pâleur et le sang is presented as the representative of these forces and as having "pouvoirs magiques - et maléfiques" (37). She warns other characters when they offend the powers, and she predicts punishment. Her death, it is hinted, is really murder, and this is one cause of the misfortunes that befall the island. Isabelle Bowley is also shown as having a special relationship with the island and the forces hidden in it. She is aware that "sa vie s'engageait sous la surveillance de forces impérieuses" (51), and she wanders the island "comme au milieu de son règne" (65). It is she who stands against her mother's liaison with an outsider, and who plots vengeance against the latter when she becomes convinced that he killed her father. It is also Isabelle who opens her brother's eyes to what has happened and who turns him into an avenger of the family and of the powers hidden in the island.

In many cases, it is concerns from the outside world that disturb the harmony of the protected communities in Bréhal's fiction. Daniel's secure childhood world is menaced by the financial problems faced by his mother and aunts. In Les Étangs de Woodfield, the outbreak of war in Europe destroys the comfortable isolation of the rich bourgeois. In other cases, an intruder from the outside causes disorder. When Daniel's aunt takes a lover, she is seen as betraying the family with an outsider, and Daniel exclaims: "Fanny trahissait notre existence et notre histoire" (L'Enfant au souffle coupé, 78). Deborah Lockwood also becomes involved with a man from outside who breaks her relationship with her sister and with her friend Angela. In La Pâleur et le sang, the forces that govern the lives of the islanders are first offended when Bernard Bowley marries an outsider who dislikes the island and who becomes "mauvaise herbe enracinée à Vindilis" (109). However, the major offence is caused by Gonéri Lenn, a man from the mainland who embarks on a liaison with Bernard Bowley's wife. He is suspected of killing la Groac'h, who represents the powers of the island, and Bowley himself, who is the island's guardian. The natural disasters that strike the island are caused mainly by his acts, and they do not cease until he and his mistress are killed. By contrast, Emmanuel Kirkland is an outsider who accepts the rules of the rich members of 
Woodfield society, to which he seeks access. He causes no offence, and he even converts to Judaism in order to marry one of the wealthiest women in this society. He enters Woodfield "comme on entre dans les ordres" (Les Étangs de Woodfield, 185).

In addition to the external forces that threaten the security of Bréhal's characters, there are dangers that come from within, and even from those who apparently seek safety and order. Several characters, while fearing the outside world, feel stifled in their own world. Daniel, for example, often longs to leave his home to live by the sea. He sows discord among the women around him, and his revolt culminates in the murder of Fanny. This act breaks up the little group, and, even though he is not suspected of causing Fanny's death, it achieves his goal, for he is sent to a school near the sea. Throughout the novel, the sea is a symbol of his wish to be free, while the river that he can see from his home represents both freedom and the secure boundaries of his little world. The asthma that afflicts him is another double symbol, for it conveys the danger of forces that cut him off from his home and the very breath of life, but it is also a reaction to the stifling atmosphere of that home.

Deborah Lockwood is another character who rebels against the safe haven of her home. Her provocative behaviour at the ball given for her eighteenth birthday is one sign of her revolt, and taking a lover from the outside is another. The first of these acts leads to her aunt's illness and death, and the second causes her friend Angela, in a fit of jealousy, to set fire to the nearby woods and almost to destroy the wealthy district of the town. In La Pâleur et le sang, Loïc Bowley also turns against the island. After being sent to Paris to complete his education, he becomes infatuated with his uncle, a frivolous, dashing officer who represents a society that now claims Loïc. He forgets his ties to Vindilis, and he abandons his interest in its traditions. "A travers la personne de son oncle," we are told, "Loïc se passionnait pour tout ce qui échappait à son passé, à son ille" (112). When forced by his father's death to return, he accepts the friendship of Gonéri Lenn, the enemy of the island. Only when Isabelle makes him see the folly of his ways does he avenge his father and avert chaos. 
Another danger to the calm and order of these protected worlds comes from the disordered passions that certain characters feel. Daniel's sexual attraction to his young aunt and his jealousy when she takes a lover lead him to destroy her and his world too. Angela's passion for Deborah and her jealousy when the latter becomes involved with John David Spencer, cause her to try to burn down Woodfield. Deborah's passion for Spencer leads her to her own voluntary disappearance after he is killed in the war. The "désir comme un crime, puissant et banal" (La Pâleur et le sang, 120) that grows up between Helen Bowley and Gonéri Lenn causes unrest among the islanders and provokes the wrath of hidden forces.

Even memories can become a destructive influence. Charlotte, for example, is uneasy, disturbed to the point of illness and mental breakdown, when figures from her past seem to appear. The return of Louis, a beloved brother who died when she was young, is particularly disturbing. The secure world of Daniel's childhood is shaken by memories of the war and the exodus from his home. Both Laurent Kreutzer and his wife seek to forget the murder of their son, but his ghost returns to disturb their calm.

Yet memories play a privileged role in the worlds that characters try to construct, and they are shown as being an essential part of human experience. Indeed, memories help to create the identity of any individual. Charlotte in Portrait de femme, l'automne, while deeply disturbed by the ghosts of her past, realises that these are part of her life, and that they have contributed towards making her what she is now. Laurent Kreutzer is also aware of this, and one of his greatest fears, as he lies dying, is that his memory is failing him and that he is, therefore, ceasing to exist even before he dies. But it is Daniel whose life is most obviously linked to memories. His asthma, his protected childhood and his Jewish background all remind the reader irresistibly of Proust's Marcel. Like Marcel, he also has to learn that his salvation lies in memories and in his attitude to the past. He does not fully achieve individuality and knowledge of himself until he is reconciled to the memories of suffering and injustice inflicted on his family. When he rejects this past in a fit of rage and calls his aunt "sale juive" (144), she locks him in the cellar where 
his family hid from the Nazis, telling him: "Dans cette cave, peut-être, éprouveras-tu enfin ce qui te manque depuis toujours: une mémoire" (145). The reason why he thinks so much about his dead father is that this man represents the past that shaped him and still governs him. The absence of his father is felt as a lack at the centre of his own being, and the boy's longing for his father causes him to imagine the man returning from the dead to speak to him.

Bréhal's characters thus find themselves living in what appears to be a quiet haven of order and coherence, but the very existence of which is menaced by forces from without and within. Their identity, which is closely tied to the worlds in which they live, is undermined by these forces, by their fear of memories, and by their desire to escape. But a possible solution to these threats is suggested. In all of Bréhal's novels, art is proposed as a likely means of achieving the protection that the secure little worlds, so patiently constructed, seem unable to provide.

Two art forms are explored as potential means of protection. The first of these is music, which plays an important role in Sonate au clair de lune. It is seen in this work as providing the calm and harmony that the Kreutzers' home is unable to create. Rent by internal discord and threatened by death, the characters are filled with a sense of disorder. Sarah in particular is dismayed by the breakdown of her marriage. Yet, as she listens to a piano sonata played by her daughter, she is filled with a sense of calm provoked by "des notes séparées, qui s'accordaient harmonieusement au silence" (143). As the novel ends, the whole family, disturbed by the uncertainties of a new century, is comforted to hear Geoffroy playing a sonata that is "empreinte d'une sérénité véritable" (254). Music becomes for them a protection "offrant ses enchantements et ses consolations" (76).

For Laurent Kreutzer, music is associated with a time when he was a concert pianist, and it keeps alive memories that might otherwise disappear. It thus outlasts time, but, because is does so, it is incompatible with his own knowledge that he must soon die. Consequently, he stops playing when he discovers that he has an incurable illness, believing 
that "l'éternité de la musique exigeait qu'il eût lui-même l'illusion d'être immortel" (87). Music thus becomes a reminder of his own ephemeral nature. However, even under these circumstances, he too finds calm and consolation in it. As he listens to his grandson playing, he even accepts his own death: "A ce moment, il voulut mourir" (253). This wish is granted, and he dies - happily, one assumes.

The art that is most consistently examined, however, is that of storytelling and writing. This is partly because stories are closely linked to memories and past events for these characters. Daniel loves his mother to talk about the past, especially when it concerns his father. These accounts come alive and are as vivid to him as the present. The group of islanders who meet to recount Vindilis's legendary past are keeping alive a collective past and preserving the memory of a people. Stories thus become a means of keeping memories alive and gaining some measure of victory over time. As he listens to the tale of his family's misfortunes during the war, Daniel resolves to play his part in the process by telling the story himself one day. He says: “Ce passé $m$ 'appartenait, un jour j'en ferais le mien, un jour je le raconterais à d'autres, telle une épreuve subie par mon propre corps" (L'Enfant au souffle coupé, 43).

The need to write down such stories is felt by several of Bréhal's characters. The story-tellers in La Pâleur et le sang already possess a written account of the island's legends in the form of le livre de Ballémor, a manuscript written by a monk from the island that is discovered in the Bowley library. They follow the monk's example by writing their own accounts of events that they witness. The novel itself is presented as the written record of certain events narrated by one of the group of storytellers. Les Étangs de Woodfield is another written record, set down in turn by three of its characters. Charlotte in Portrait de femme, l'automne is a novelist who, from her earliest childhood, felt the need to write, and who covered pages in exercise books with her writing.

Writing gives a certain coherence to the events described, providing an ordered interpretation that events themselves often seem to lack. Hence, Daniel discovers letters from his father to his aunt that indicate 
an affair between the two. The idea of his father's past that he once held is altered by this written evidence, giving it an order that also explains the present conduct of those with whom he lives. When images and people from her past disturb Charlotte's peace, her solution is to write a book that incorporates them. She imagines her memories as a series of waves spreading across the calm surface of her life. These waves must be stopped, held static in the written text: "Elle les voyait onduler, se soulever. Chacune porteuse d'un souvenir, d'un accident, d'un événement. Serait-il possible d'en immobiliser quelques-unes et d'en expliquer le contenu?" (Portrait de femme, l'automne, 21).

Memory is just one of the powers with which Bréhal's characters come to grips by writing. External forces generally, symbolised by the strange powers that beset Vindilis, may also be tamed to some extent by the written word. In La Pâleur et le sang, the group of characters who form themselves into a community to read, tell and write down stories about the forces that govern the island, are attempting to "entrer en liaison avec des forces secrètes" (16). They are imitating the Druids and sorcerers of old, who, by recording tales about the island, "prétendaient instruire l'Univers des forces merveilleuses dont ils étaient les témoins" (17). As witnesses of such forces, they gain their favour and counteract the offences to them committed by certain other characters. The story-tellers believe that "quiconque intervenait en faveur de ces forces s'évitait le danger d'en être un jour victime" (18). Consequently, after the forces have been particularly destructive, the story-tellers write down their account of events, and Isabelle reads it aloud on the beach. It is as though, by celebrating these powers in writing, they are attempting to appease them. After several other such natural disasters, the story-tellers meet to read the livre de Ballémor and to tell stories. Significantly, in all the damage done by the storms, the livre de Ballémor remains unharmed in its hiding place in the ruins of the convent. The forces clearly respect the written account of their power.

It is not just supernatural forces such as these that are rendered less dangerous by the power of writing. The same is true of many of the dangers and fears that beset human beings. When Charlotte writes about 
her memories and the power of death, and when characters in Les Étangs de Woodfield relate in writing their fear of time, they seem to make these perils less immediate. Merely to name and acknowledge them distances the writer from them, making him or her a witness on the sidelines rather than a participant who is menaced by events. This is why Isabelle informs the story-tellers that, having told Loïc about the events that took place during his absence, they have completed their task. Now it is up to Loïc to act and to seek revenge. The story-tellers are no longer directly involved, and stand at one remove from events and the dangers of events.

This does not mean that the writer's role is unimportant. Indeed, it is essential, for the writer records events that would otherwise be lost, and sets them down in ordered fashion. It is from stories told to him that Loïc learns what must be done, and it is the story-tellers who explain to the islanders the actions taken by Loïc. Finally, it is one of their number who passes on to us the account that we read, who puts order into the chaos of events, and who preserves part of the collective past of Vindilis.

By preserving for the reader an account of events, the writer's word is also seen as achieving a measure of victory over time itself. The family name, written on a plaque on his door, seems to Daniel to give that name a certain permanence. This is why he writes his name on the wall of the garden for his aunts and mother to see, "fermement résolu à le laisser à jamais ainsi, à la vue de toutes, solitaire et nu" (26). He also writes the date in the sand of the riverbank just before killing his aunt "pour ne plus jamais l'oublier" (L'Enfant au souffle coupé, 195). Charlotte has recourse to writing in order to record and preserve her past: "Charlotte désirait furieusement raconter, tremper ses souvenirs dans l'argile pour les rendre durs, à jamais" (Portrait de femme, l'automne, 41). Jane Lockwood, Angela Greene and Emmanuel Kirkland all write down their memories in order to give them permanence. The story-tellers in La Pâleur et le sang decide to record their tales in writing rather than just tell them to one another because the written form seems more lasting. As one of them explains: "Nous, fils et filles de pêcheurs et de paysans, à la lueur d'une flamme vacillante, transcrivîmes les épisodes de la tempête blanche dans le grand 
livre des légendes. Si nous n'en réchappions pas, demeureraient après nous le souvenir d'une communauté disparue" (167-8).

In the process of achieving a kind of permanence for the events and people described, the writer also gains a measure of durability and identity for himself or herself. Charlotte realises that, by recording and ordering events from her past, she is also trying to grasp herself. The past that she describes is her past, and therefore part of her identity: "Tout ce qu'elle avait vécu...rien ni personne ne pourrait le lui contester ou le lui voler" (69). As she looks at the words that she has written down, she concludes: "Quel pourrait être le lien entre tous ces mots, tous ces noms, sinon elle-même?" (98). Jane Lockwood likewise finds that, while writing about those whose lives have crossed her own, "je me pénètre d'une importance" (Les Étangs de Woodfield, 48).

By contrast, those who reject writing do not achieve this kind of stability. While Charlotte refuses to have children, preferring to seek her posterity and permanence in the books that she produces, her sister looks for solace and stability through her son. When her son affirms his freedom to live his own life, he escapes her, and she feels lost. In Les Étangs de Woodfield, the only major character who refuses to write down her experiences is Deborah. Fittingly, she is the one who simply disappears at the end of the novel, leaving little trace. The only permanence that she does acquire is provided by others who write about her.

Writing is even seen as a means of making the past and memories of it seem less threatening. It thus becomes a kind of victory over the past. Hence Daniel looks forward to the day when, like Proust's Marcel, he will write about his life. The disturbing events of his earlier life will become "de quoi raconter, de quoi écrire un jour ma prochaine victoire" (L'Enfant au souffle coupé, 203). Charlotte discovers that by writing about the phantoms from the past who disturb her peace, she lays them to rest. Even the threat of death seems more bearable if one openly acknowledges it in writing. Jane Lockwood, as she tells the story of the deaths of her aunt, her mother and her sister, finds in this account "un règlement de compte de la vie à la mort" (Les Étangs de Woodfield, 47). Charlotte's first 
novel is seen by her as a means of helping her dead brother overcome a life of failure and a premature death, a way of bringing him to life. It is "un peu la revanche que Louis prendrait, à travers elle, sur la vie" (Portrait de femme, l'automne, 93).

Writing may also be victory over the generally disordered nature of existence as Bréhal's characters experience it. Charlotte's attempts to order her memories into stylish texts is an attempt to give form to the chaos of experience. In this context, Bréhal's own style (which, as we have seen, is the most immediately striking characteristic of his work for most critics) assumes considerable importance. He describes disturbing and often violent events, forces of great destructive power, in a language remarkable for its calm beauty. He uses style to give order to the disorderly, to tame what is hostile and destructive.

Such "victories" as these are relative, of course. Bréhal does not adopt a simplistic attitude that sees writing as inevitably providing refuge against the forces that assail the individual. He is well aware that it is an imperfect instrument and that it puts often impossible demands upon the writer. He knows that words, as well as creating identity and a kind of permanence, also put the speaker and the writer in the power of others, who may interpret words as they see fit. Deborah refuses to write because she prizes her freedom, and, when John David Spencer first speaks to her, then tells her his name, she knows that these words put him to some extent in her power. As he says his name, "il se rend une première fois" (Les Étangs de Woodfield, 143), and, from then on, he falls more and more into her grasp. The speaker, and even more so the writer, risk actual loss of identity when their words are taken over, as it were, by the reader or listener.

Another problem arises from the fact that there are elements of any writer's life that are apart from his or her activity as a writer, and that escape definition in the written text. No individual can be a writer all the time, defining every moment of his or her life in written form and creating a total identity. As Deborah Lockwood puts it: "Même si le mot écrivain était juste, il ne définerait que quelques moments de la vie, à 
l'exclusion des autres, où l'écriture, tout de même, est absente" (Les Étangs de Woodfield, 162).

Nor is writing necessarily a guarantee against time and death. It is only by chance that le Livre de Ballémor is preserved and found, and, had this not happened, much of the legendary past contained in it would have been lost. Even if it does survive, a written record cannot seize all of the world around it and give a comprehensive account of the past. Charlotte faces moments of despair when she realises that what she writes are "ces phrases qui cherchaient à illustrer la vie, sans toucher le fond du chaos, les infimes nuances à travers quoi son esprit cherchait à se frayer un chemin" (Portrait de fermme, l'automne, 19). No written text can convey accurately certain things and what they mean to her. When she remembers how her brother used to play the piano, she thinks: "Comment faire entendre la musique que Louis jouait au piano, qui montait jusque dans les chambres? Impossible" (20). Faced with these difficulties, Charlotte is tempted to see her books as pointless. The novels that she has written become for her "ces pâles trophées [qui] inspiraient désormais une telle indifférence" (15).

Art is not seen by Bréhal as easy consolation, but as a hard and demanding taskmaster. Charlotte's brother, knowing that he will never be the brilliant concert pianist that he dreamed he would be, commits suicide. His art is simply too demanding, and he prefers not to remain a mediocre performer. John David Spencer, also realises that he lacks the talent to achieve anything lasting as a writer. His solution is the opposite of that chosen by Charlotte's brother: he contents himself with producing the second-rate. He writes "des pages sans suite, peu importe" (Les Étangs de Woodfield, 176). For him, writing becomes "une occupation machinale" (176), a way of passing time rather than defying it. Deborah aptly describes his activity as: "Écrire pour le train...écrire pour ne rien dire" (162).

Charlotte herself neither abandons her art in despair, nor treats it lightly. Whatever the difficulties, and whatever her doubts about her own talent, she continues to write serious works that try to come to grips 
with the forces menacing her world. She at least attempts to capture and render harmless in her writing all those things that she fears and that obsess her. "Comment dire TOUT?" she wonders, yet she tries to do just that (Portrait de femme, l'automne, 56). The story-tellers in La Pâleur et le sang, and the narrators of Les Étangs de Woodfield, make the same resolution. This is also the challenge that Bréhal himself takes up. $\mathrm{He}$ produces novels that expose all the dangers faced by the fragile worlds that men and women create for themselves. At the same time, these works are an attempt to create a firmer, more satisfactory protection.

\section{Notes}

"Gabrielle Robin, "Nicolas Bréhal, le fol espoir de tout dire," Le Monde [des Livres] No. 1144 (28 novembre 1980), 19; Alain Bosquet, "Un Romantique grave et précis," Le Magazine Littéraire No. 234 (octobre 1986), 48.

${ }^{2}$ Bosquet, op. cit., 48.

${ }^{3}$ Gérard-Humbert Goury, "Nicolas Bréhal: Les Étangs de Woodfield," Le Magazine Littéraire No. 143 (décembre 1978), 59.

${ }^{4} \mathrm{I}$ have used the following editions of Bréhal's works, all of which are published in Paris: Les Étangs de Woodfield (Mercure de France/Folio, 1978); Portrait de femme, l'automne (Mercure de France, 1980); La Paleur et le sang (Mercure de France/Folio, 1983); L'Enfant au souffle coupé (Mercure de France, 1986); Sonate au clair de lune (Mercure de France, 1991). 